\title{
Neocentric X-chromosome in a girl with Turner-like syndrome
}

\author{
Morteza Hemmat ${ }^{1 \dagger}$, Boris T Wang ${ }^{1 \dagger}$, Peter E Warburton ${ }^{2}$, Xiaojing Yang ${ }^{1}$, Fatih Z Boyar ${ }^{1}$, \\ Mohammed El Naggar ${ }^{1}$ and Arturo Anguiano ${ }^{1,3^{*}}$
}

\begin{abstract}
Background: Neocentromeres are rare human chromosomal aberrations in which a new centromere has formed in a previously non-centromeric location. We report the finding of a structurally abnormal $\mathrm{X}$ chromosome with a neocentromere in a 15-year-old girl with clinical features suggestive of Turner syndrome, including short stature and primary amenorrhea.

Result: G-banded chromosome analysis revealed a mosaic female karyotype involving two abnormal cell lines. One cell line (84\% of analyzed metaphases) had a structurally abnormal X chromosome (duplication of the long arm and deletion of the short arm) and a normal X chromosome. The other cell line (16\% of cells) exhibited monosomy X. C-banding studies were negative for the abnormal X chromosome. FISH analysis revealed lack of hybridization of the abnormal X chromosome with both the X centromere-specific probe and the "all human centromeres" probe, a pattern consistent with lack of the $X$ chromosome endogenous centromere. A FISH study using an XIST gene probe revealed the presence of two XIST genes, one on each long arm of the iso $(\mathrm{Xq})$, required for inactivation of the abnormal $X$ chromosome. R-banding also demonstrated inactivation of the abnormal X chromosome. An assay for centromeric protein C (CENP-C) was positive on both the normal and the abnormal $X$ chromosomes. The position of CENP-C in the abnormal $X$ chromosome defined a neocentromere, which explains its mitotic stability. The karyotype is thus designated as 46,X,neo(X)(qter- > q12::q12-> q21.2- > neo- > q21.2-> qter)[42]/45,X[8], which is consistent with stigmata of Turner syndrome. The mother of this patient has a normal karyotype; however, the father was not available for study.
\end{abstract}

Conclusion: To our knowledge, this is the first case of mosaic Turner syndrome involving an analphoid iso(Xq) chromosome with a proven neocentromere among 90 previously described cases with a proven neocentromere.

Keywords: Neocentromere, Turner Syndrome, X-inactivation, Mosaicism

\section{Background}

Neocentromeres are rare human chromosomal aberrations that have apparently formed within interstitial chromosomal sites that have not previously been known to express centromere function. An acentric fragment that would usually be lost can rescue itself by generating a neocentromere, which functions similarly to a normal centromere. Neocentromeres lack $\alpha$-satellite DNA and have consistently demonstrated the presence of all

\footnotetext{
* Correspondence: Arturo.L.Anguiano@questdiagnostics.com

${ }^{\dagger}$ Equal contributors

'Cytogenetics Dept, Quest Diagnostics Nichols Institute, San Juan Capistrano, CA, USA

${ }^{3}$ Quest Diagnostics Nichols Institute, 33608 Ortega Highway, San Juan Capistrano, CA 92690, USA

Full list of author information is available at the end of the article
}

centromere proteins except centromeric binding protein $(C E N P-B)[1]$.

As summarized by Liehr et al. [2], neocentric chromosomes are based on a U-type exchange and the formation of inverted duplicated chromosomes [2-4] or inverted duplications on acentric markers [5]. The resulting marker comprises two copies of the chromosome segment oriented as a "mirror image" around the breakpoint. Neocentromere formation occurs at an interstitial site apparently unrelated to the site of the breakpoint. However, the generation of the neocentromere allows the recovery of the acentric fragment that would otherwise have been lost and thereby restores a balanced karyotype [6]. Extensive analysis of neocentromere formation has led to the conclusion that neocentromere activation occurs via an unknown epigenetic mechanism that, in

\section{Biomed Central}


effect, converts a previously non-centromeric genetic locus into a functional neocentromere that associates with all of the proteins involved in active centromere function [6]. This process has recently been described as neocentromerization [7].

DNA polymorphism studies performed in five cases indicated that human neocentromeres can form either during meiosis [8,9] or mitosis [8]. Once formed, they can also be transmitted through mitosis and meiosis [5].

Mosaicism might be a consequence of mitotic instability of neocentric marker chromosomes that have been meiotically transmitted from the previous generation [10-12]. This would be due to either suboptimal function of the neocentric kinetochore or selection pressure against cells containing the marker [13]. Alternatively, mosaicism could arise from a meiotically derived marker if neocentromere function was not established at the time of meiotic rearrangement. In this scenario, neocentric function would develop after several post-fertilization cell divisions, during which some of the markers would be lost [14].

To date, more than 90 cases of neocentromeres involving 20 different human chromosomes have been described [15-24], including only two cases of neocentric $\mathrm{X}$ chromosome. $\mathrm{Yu}$ et al. reported a case with a supernumerary neocentric marker chromosome, which consisted of partial duplication of the short arm of $\mathrm{X}$ chromosome in $100 \%$ of G-banded metaphases [22]. The second case was mosaic for $45, \mathrm{X}$ and $46, \mathrm{X}, \mathrm{rec}(\mathrm{Xq})$ with features of Turner syndrome [25]. We report here a patient with features of Turner syndrome who was mosaic for two cell lines, including 45, $\mathrm{X}$ and 46,X,i(Xq); the latter contained an active neocentromere and was monosomic for Xp and partially trisomic for Xq.

\section{Results}

Chromosome analysis of cultured lymphocytes by Gbanding revealed a mosaic female karyotype involving two abnormal cell lines. One cell line $(84 \%$ of analyzed metaphases) had a normal $\mathrm{X}$ chromosome in addition to a structurally abnormal X chromosome with duplication of the long arm and deletion of the short arm (Figure 1). The other cell line (16\% of cells) exhibited monosomy X (Figure 2). The proband's mother had a normal female karyotype, 46,XX. The father was not available for karyotyping. However, the abnormal $\mathrm{X}$ is very likely to be de novo.

The preliminary FISH analysis revealed lack of hybridization of the abnormal $\mathrm{X}$ chromosome with both the $\mathrm{X}$ centromere-specific probe and the probe for all human centromeres. This pattern was consistent with absence of an endogenous centromere on the abnormal X chromosome (Figures 3 and 4). This was also confirmed by negative $\mathrm{C}$-banding performed on metaphases with an abnormal X.

Further FISH study for the XIST gene revealed that 2 copies of this gene were present on the abnormal $\mathrm{X}$ chromosome (Figure 5). Moreover, the R-banding analysis revealed that the abnormal $\mathrm{X}$ chromosome was
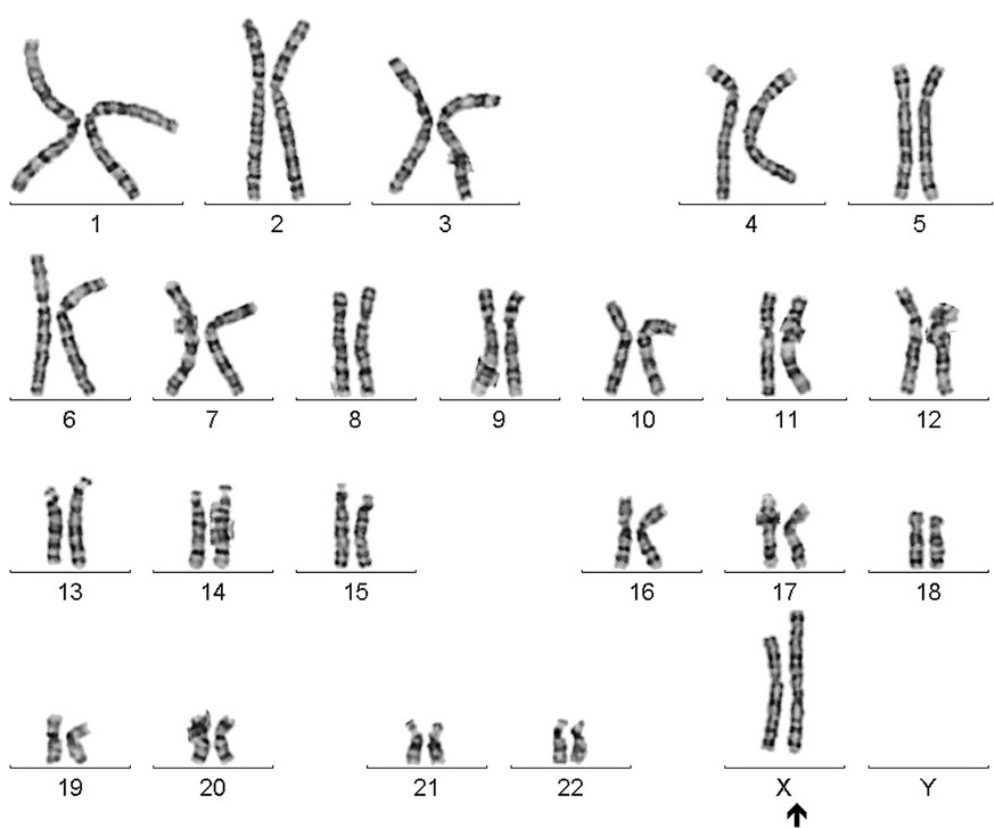

Figure 1 G-banded karyotype showing the cell line with one normal and one abnormal X chromosome with duplication of long arm and deletion of short arm. 


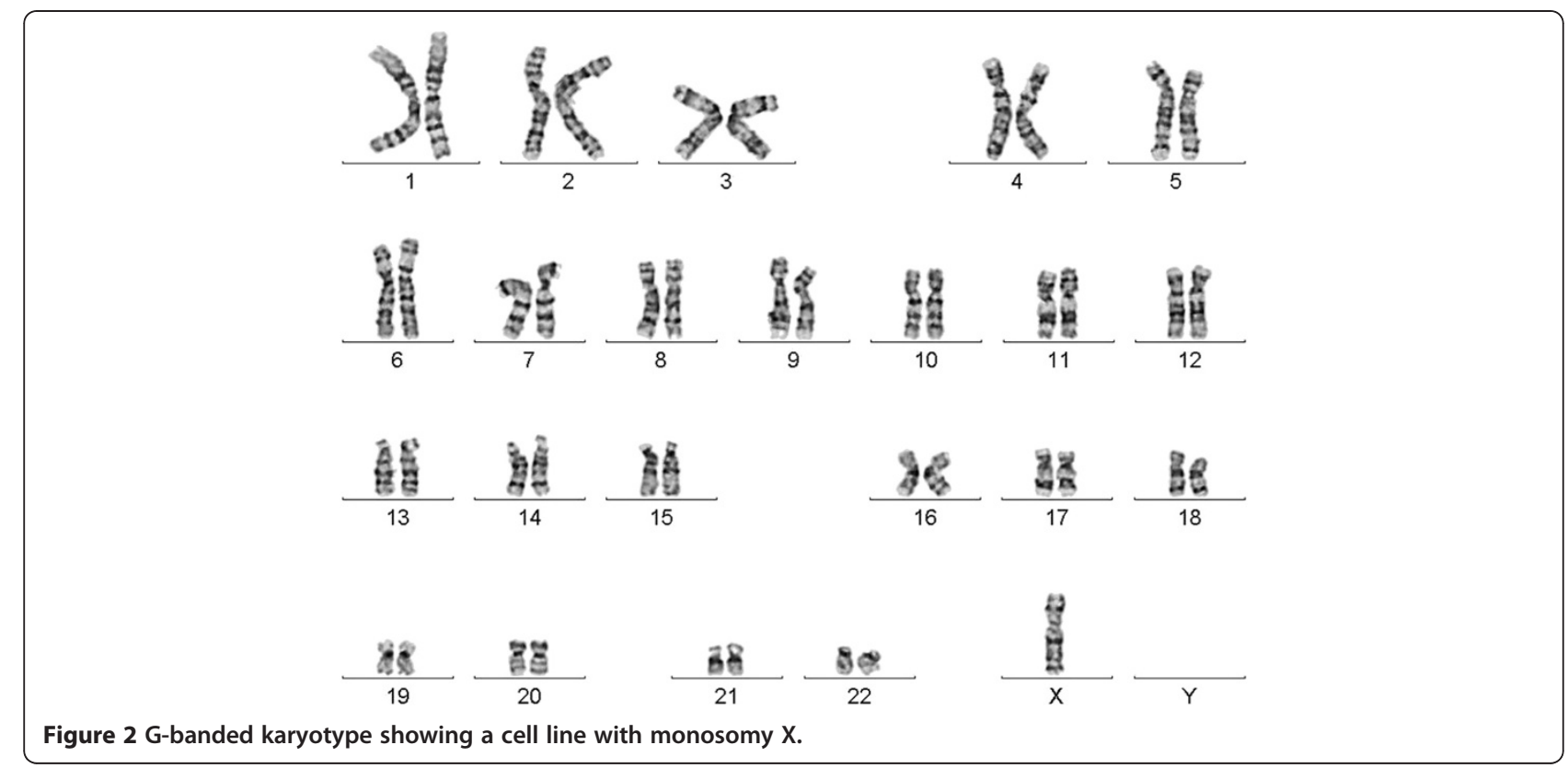

inactive in all cells (Figure 6). Figure 7 shows the results for combined whole $\mathrm{X}$ chromosome painting FISH and simultaneous immunofluorescence staining using antiCENP-C antibody. The CENP-C assay was positive on both the normal and abnormal $\mathrm{X}$ chromosomes, as indicated by the whole $\mathrm{X}$ chromosome paint, confirming the presence of a neocentromere in the abnormal $\mathrm{X}$

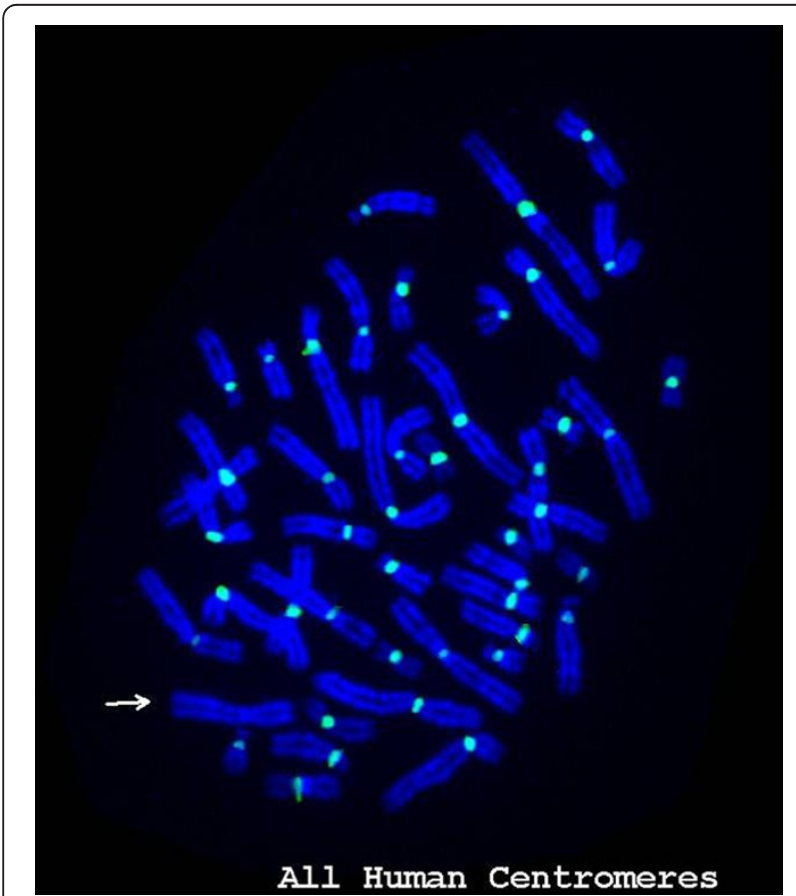

Figure 3 FISH image of metaphase using a pan-a-satellite probe (green). Hybridization signals are present on all chromosomes except the abnormal X. chromosome. The novel position of CENP-C in the abnormal $\mathrm{X}$ chromosome defined a neocentromere, which explains its mitotic stability

\section{Discussion}

The incidence of Turner syndrome is approximately 1 in 4000 female live births. Fewer than $5 \%$ of Turner syndrome cases are mosaic, with one cell line carrying one normal and one abnormal $\mathrm{X}$ chromosome. Our case of

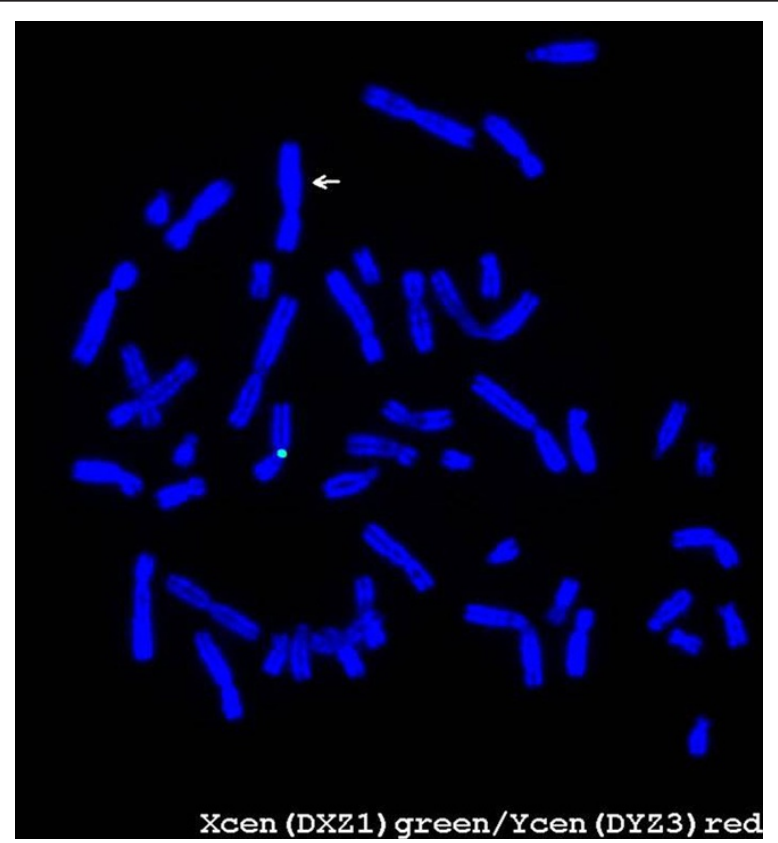

Figure 4 FISH image of metaphase using X-centromere probe. The abnormal $X$ chromosome lacks a hybridization signal. 


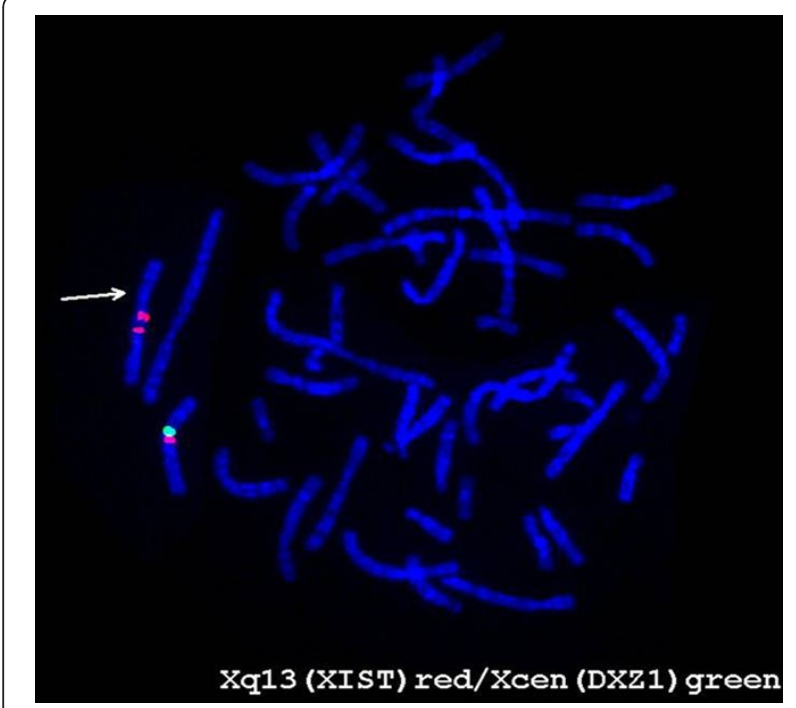

Figure 5 FISH image of metaphase using XIST gene probe (red). The abnormal $X$ chromosome has two hybridization signals, which indicates duplication of Xq.

mosaic Turner syndrome is the first to be reported with the presence of an isochromosome for $\mathrm{Xq}$, in which a neocentromere is present in lieu of a normal centromere. The karyotype of our patient was thus designated as 46,X,neo $(\mathrm{X})$ (qter- > q12::q12 > q21.2- > neo- > q21.2- > qter)[42]/45,X[8], based on the results obtained from chromosome and FISH analysis.

This iso $(\mathrm{Xq})$ essentially represents an inverted duplication of $\mathrm{Xq}$, which possibly occurred at maternal meiosis $\mathrm{I}$; this inversion apparently involves anomalous or Utype crossing over at Xq12 as described by Warburton [4]. The duplicated copies are mirror images around the

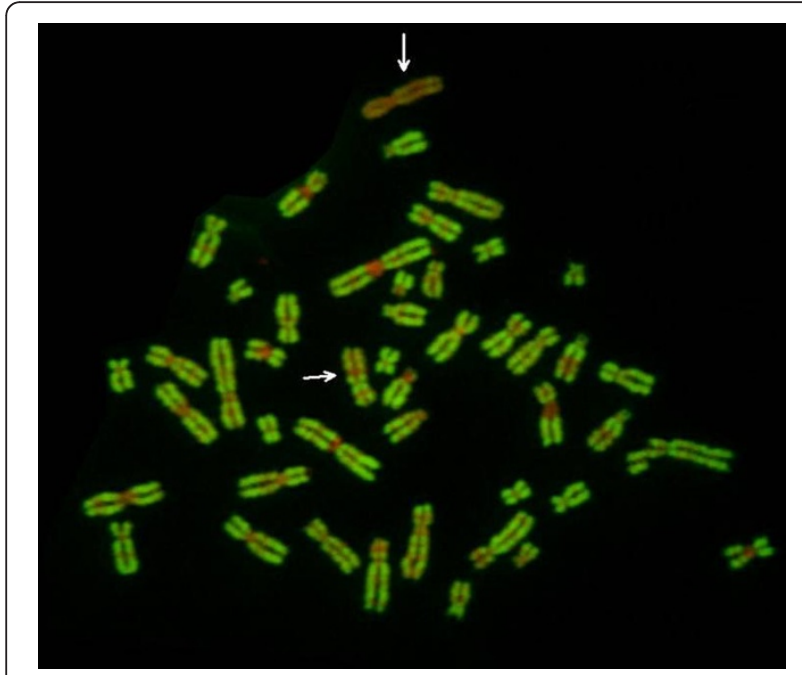

Figure 6 R-banding analysis reveals the abnormal $X$ chromosome to be inactive.

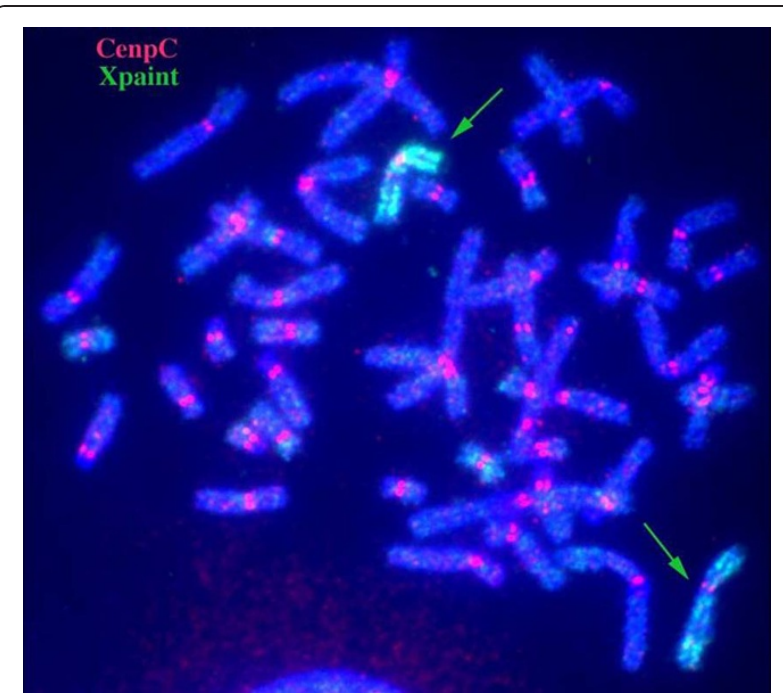

Figure 7 Centromeric protein C (CENP-C) assay. CENP-C (red signal) is present on all the chromosomes and defines the presence of a neocentromere in the abnormal $X$.

breakpoint Xq12 (Figure 8). This acentric fragment would usually be lost but has rescued itself by generating a neocentromere, which functions similarly to a normal centromere, at one of the duplicated regions. Lack of a centromere and presence of a neocentromere in the abnormal X chromosome of our patient was confirmed by FISH and CENP-C staining. The novel position of CENP-C and absence of alpha satellite DNA in the abnormal $\mathrm{X}$ chromosome defined a neocentromere, which also explains its mitotic stability. The mosaicism observed in the karyotype of our patient is very likely a consequence of gradual formation, stabilization, and functioning of the neocentromere after several postfertilization cell divisions, during which the iso(Xq) may be lost in a proportion of cells $[14,26]$.

$\mathrm{X}$-inactivation is the process by which most genes on one of the two $\mathrm{X}$ chromosomes in females are silenced epigenetically. In normal females cells, the choice of which X chromosome (paternal or maternal) is to be inactivated is a random one that is then maintained in each clonal lineage. However, an abnormal X chromosome is always the inactive one if it is structurally unbalanced. This was confirmed in our patient by R-banding, which showed that the abnormal $\mathrm{X}$ was inactivated in all metaphases carrying this abnormal chromosome. Presence of an XIST gene, the key master locus for X inactivation, at band Xq13 was also confirmed by FISH: the abnormal $\mathrm{X}$ chromosome carried two copies, and the normal X carried one. The XIST gene is normally expressed only from the inactive $\mathrm{X}$ and is transcriptionally silent on the active $\mathrm{X}$. The selective inactivation of the abnormal $\mathrm{X}$ in our patient likely results in a protective effect from possible abnormalities attributable to it. 


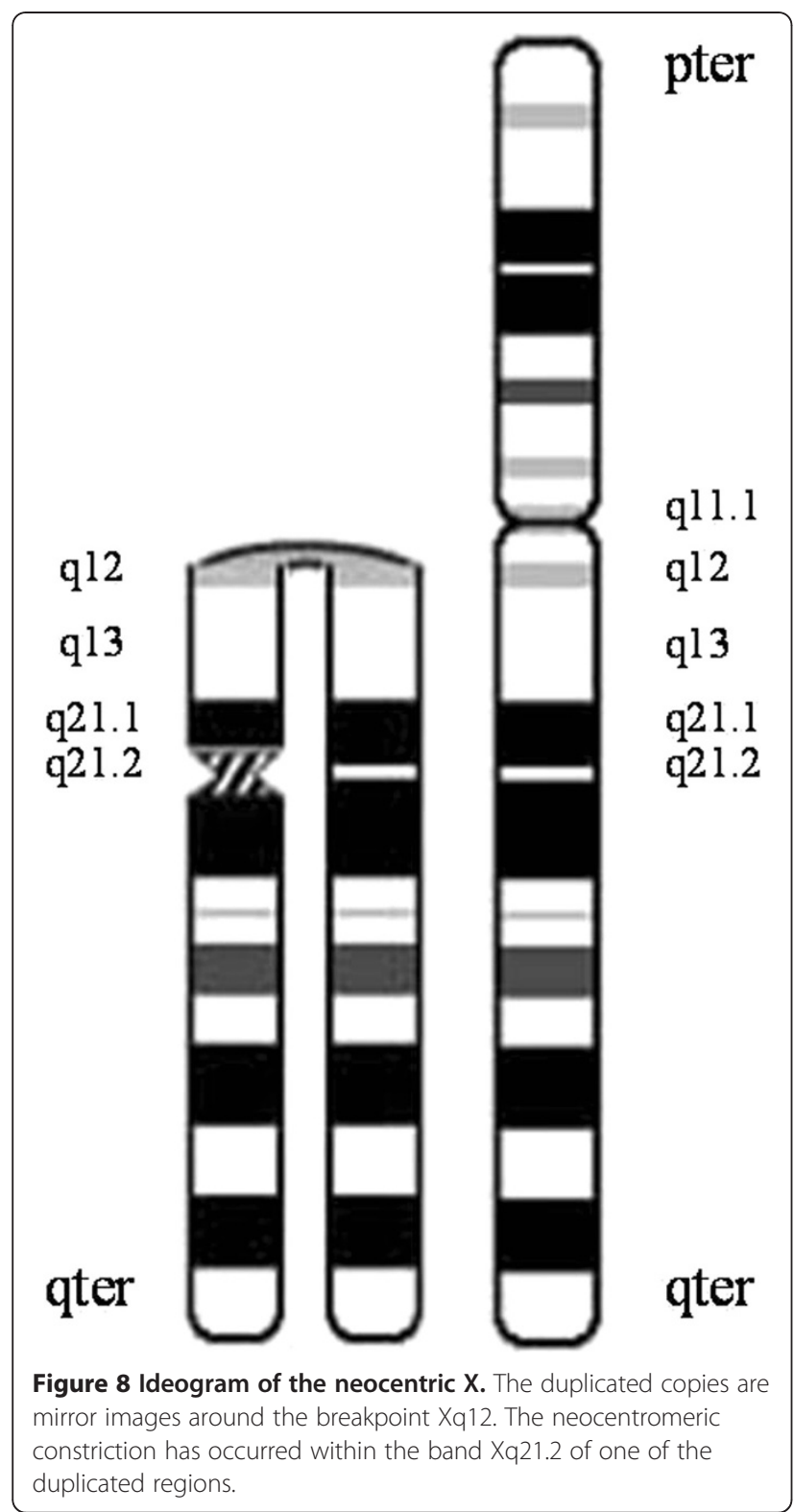

\section{Conclusion}

To our knowledge, this is the first case of mosaic Turner syndrome involving an analphoid iso(Xq) chromosome with a proven neocentromere among 90 previously described cases with a proven neocentromere.

\section{Methods}

\section{Chromosome analysis}

A peripheral blood sample from a 15-year-old girl was referred to our laboratory for cytogenetic analysis. Her clinical features were suggestive of Turner syndrome, including short stature and primary amenorrhea. Metaphase chromosome preparations were obtained from the patient and her mother according to standard procedures. Chromosomes were analyzed with G-banding at the resolution level of 550 bands. C-banding was also performed on the patient's metaphase cells. The father was not available for karyotyping.

\section{Analysis by Fluorescence in situ hybridization (FISH)}

FISH analyses were carried out according to the protocols recommended by the manufacturer of the DNA probes. This study used $\alpha$-satellite DNA probes for all chromosome centromeres, a mixture of probes for $\mathrm{X}$ chromosome centromere (DXZ1) and Y chromosome centromere (DYZ3), a locus specific probe for XIST gene located at Xq13 (spectrum orange)/CEP X centromere (spectrum green) and a probe for whole chromosome painting.

\section{Analysis by R-Banding}

$\mathrm{R}$-banding for evaluation of X-inactivation status was then performed. To obtain RBA (reverse banding by 5 -bromodeoxyuridine and acridine orange), the culture techniques were modified by adding $75 \mu \mathrm{g} / \mathrm{mL}$ 5-bromodeoxyuridine 6.5 hours before harvest, and slides were prepared by a modification of the technique of Van Dyke et al. [27].

\section{Ethical approval and consent}

These studies were performed on anonymized samples received in the clinical laboratory and thus were exempted from the requirement for consent by an opinion for the Western Institutional Review Board.

\section{Analysis by CENP-C staining}

To investigate the presence of a neocentric marker chromosome, immunofluorescence analysis with antibody to centromere protein C (CENP-C) was employed on fresh 3:1 methanol:acetic acid fixed chromosomes according to published protocols [18].

\section{Competing interests}

The authors declare that they have no competing interests.

\section{Authors' contributions}

MH First co-author; drafted and finalized the manuscript. BTW First co-author; initiated the study and finalized the manuscript. PEW conducted the immunofluoresence analysis with antibody to CENP-C. XJY performed R-banding and FISH analyses. FZB made critical comments on the drafted manuscript. MME made comments on the drafted manuscript. AA Corresponding author, final approval of the drafted manuscript. All authors read and approved the final manuscript.

\section{Acknowledgements}

The authors thank Jeff Radcliff (Quest Diagnostics) for assistance in editorial review of the manuscript.

\section{Author details}

${ }^{1}$ Cytogenetics Dept, Quest Diagnostics Nichols Institute, San Juan Capistrano, CA, USA. ${ }^{2}$ Deparment of Genetics and Genomic Sciences, Mount Sinai School of Medicine, NY, USA. ${ }^{3}$ Quest Diagnostics Nichols Institute, 33608 Ortega Highway, San Juan Capistrano, CA 92690, USA. 


\section{References}

1. Marshall OJ, Chueh AC, Wong LH, Choo KHA: Neocentromeres: new insights into centromere structure, disease development, and karyotype evolution. Am J Hum Genet 2008, 82:261-282.

2. Liehr T, Mrasek K, Hinreiner S, Reich D, Ewers E, Bartels I, Seidel J, Emmanuil N, Petesen M, Polityko A, Dufke A, lourov I, Trifonov V, Vermeesch J, Weise $A$ : Small supernumerary marker chromosomes (sSMC) in patients with a $45, X / 46, X,+$ mar karyotype - 17 new cases and a review of the literature. Sex Dev 2007, 1:353-362.

3. Liehr T, Kosyakova N, Weise A, Ziegler M, Raabe-Meyer G: First case of a neocentromere formation in an otherwise normal chromosome 7. Cytogenet Genome Res 2010, 128:189-191.

4. Warburton PE: Chromosomal dynamics of human neocentromere formation. Chromosome Res 2004, 12:617-626.

5. Murmann AE, Conrad DF, Mashek H, Curtis CA, Nicolae RI, Ober C, Schwartz S: Inverted duplications on acentric markers: mechanism of formation. Hum Mol Genet 2009, 18:2241-2256.

6. Amor DJ, Choo KH: Neocentromeres: role in human disease, evolution, and centromere study. Am J Hum Genet 2002, 71:695-714.

7. Choo KH: Centromerization. Trends Cell Biol 2000, 10:182-188.

8. Depinet TW, Zackowski JL, Earnshaw WC, Kaffe S, Sekhon GS, Stallard R, Sullivan BA, Vance GH, Van Dyke DL, Willard HF, Zinn AB, Schwartz S: Characterization of neo-centromeres in marker chromosomes lacking detectable alpha-satellite DNA. Hum Mol Genet 1997, 6:1195-1204.

9. Rowe AG, Abrams L, Qu Y, Chen E, Cotter PD: Tetrasomy 15q25rqter: cytogenetic and molecular characterization of an analphoid supernumerary marker chromosome. Am J Med Genet 2000, 93:393-398.

10. Rivera H, Vasquez Al, Ayala-Madrigal ML, Ramirez-Duenas ML, Davalos MP: Alphoidless centromere of a familial unstable inverted $Y$ chromosome. Ann Genet 1996, 39:236-239.

11. Rivera H, Vasquez Al, Garcia-Cruz D, Crolla JA: Neocentromere at $13 q 32$ in one of two stable markers derived from a $13 q 21$ break. Am J Med Genet 1999, 85:385-388.

12. Tyler-Smith C, Gimelli G, Giglio S, Floridia G, Pandya A, Terzoli G, Warburton PE, Earnshaw WC, Zuffardi O: Transmission of a fully functional human neocentromere through three generations. Am J Hum Genet 1999, 64:1440-1444

13. Amor DJ, Kalitsis $P$, Sumer $H$, Choo KH: Building the centromere: from foundation proteins to 3D organization. Trends Cell Biol 2004, 14:359-368.

14. Voullaire L, Saffery R, Earle E, Irvine DV, Slater H, Dale S, du Sart D, Fleming T, Choo $\mathrm{KH}$ : Mosaic inv dup(8p) marker chromosome with stable neocentromere suggests neocentromerization is a post-zygotic event. Am J Med Genet 2001, 102:86-94.

15. Pasantes JJ, Wimmer R, Knebel S, Münch C, Kelbova C, Junge A, Kieback P, Küpferling $P$, Schempp W: 47, X, idic(Y), inv dup(Y): a non-mosaic case of a phenotypically normal boy with two different $Y$ isochromosomes and neocentromere formation. Cytogenet Genome Res 2012, 136:157-162.

16. Haddad V, Aboura A, Tosca L, Guediche N, Mas AE, L'herminé AC, Druart L, Picone O, Brisset S, Tachdjian G: Tetrasomy 13q31.1qter due to an inverted duplicated neocentric marker chromosome in a fetus with multiple malformations. Am J Med Genet A 2012, 158A:894-900.

17. Warburton PE, Cooke CA, Bourassa S, Vafa O, Sullivan BA, Stetten G, Gimelli G, Warburton D, Tyler-Smith C, Sullivan KF, Poirier GG, Earnshaw WC: Immunolocalization of CENP-A suggests a distinct nucleosome structure at the inner kinetochore plate of active centromeres. Curr Biol 1997, 7:901-904.

18. Warburton PE, Dolled M, Mahmood R, Alonso A, Li S, Naritomi K, Tohma T, Nagai T, Hasegawa T, Ohashi H, Govaerts LC, Eussen BH, Van Hemel JO, Lozzio C, Schwartz S, Dowhanick-Morrissette JJ, Spinner NB, Rivera H, Crolla JA, Yu C, Warburton D: Molecular cytogenetic analysis of eight inversion duplications of human chromosome $13 q$ that each contain a neocentromere. Am J Hum Genet 2000, 66:1794-1806.

19. Amor DJ, Voullaire L, Bentley K, Savarirayan R, Choo KH: Mosaic monosomy of a neocentric ring chromosome maps brachyphalangy and growth hormone deficiency to 13q31.1-13q32.3. Am J Med Genet A 2005, 133A:151-157.

20. Mahjoubi F, Peters GB, Malafiej P, Shalhoub C, Turner A, Daniel A, Hill RJ: An analphoid marker chromosome inv dup(15)(q26.1qter), detected during prenatal diagnosis and characterized via chromosome microdissection. Cytogenet Genome Res 2005, 109:485-490.

21. Tonnies H, Gerlach A, Heineking B, Starke H, Neitzel H, Neumann LM: Molecular cytogenetic identification and characterization of a de novo supernumerary neocentromeric derivative chromosome 13. Cytogenet Genome Res 2006, 114:325-329.

22. Yu S, Barbouth D, Benke PJ, Warburton PE, Fan YS: Characterization of a neocentric supernumerary marker chromosome originating from the $\mathrm{Xp}$ distal region by FISH, CENP-C staining, and array CGH. Cytogenet Genome Res 2007, 116:141-145.

23. Klein E, Rocchi M, Ovens-Raeder A, Kosyakova N, Weise A, Ziegler M, Meins M, Morlot S, Fischer W, Volleth M, Polityko A, Ogilvie CM, Kraus C, Liehr T: Five novel locations of neocentromeres in human: 18q22.1, Xq27.1q27.2, Acro p13, Acro p12, and heterochromatin of unknown origin. Cytogenet Genome Res 2012, March 1. [Epub ahead of print].

24. Frenny S, Elisabeth E, Nadezda K, Anja W, Jayesh S, Manisha D, Joris A, Joris $V$, Ahmed BH, Monika Z, Thomas L: A small supernumerary marker chromosome present in a Turner syndrome patient not derived from X- or Y-chromosome: a case report. Molecular Cytogenetics 2009, 2:22.

25. Kaiser-Rogers KA, Davenport ML, Powell CM, Rao KW: A recombinant X chromosome with an atypical centromere observed in a child with Turner syndrome. Am J Hum Genet Supp/ 1995, 57:A658.

26. Reddy KS, Sulcova V, Schwartz S, Noble JE, Phillips J, Brasel JA, Huff K, Lin HJ: Mosaic tetrasomy 8q: inverted duplication of 8q23.3qter in an analphoid marker. Am J Med Genet 2000, 92:69-76.

27. Van Dyke DL, Flejter WL, Worsham MJ, Roberson JR, Higgins JV, Herr HM, Knuutila S, Wang N, Babu VR, Weiss L: A practical metaphase marker of the inactive X chromosome. Am J Hum Genet 1986, 39:88-95.

doi:10.1186/1755-8166-5-29

Cite this article as: Hemmat et al:: Neocentric X-chromosome in a girl with Turner-like syndrome. Molecular Cytogenetics 2012 5:29.

\section{Submit your next manuscript to BioMed Central and take full advantage of:}

- Convenient online submission

- Thorough peer review

- No space constraints or color figure charges

- Immediate publication on acceptance

- Inclusion in PubMed, CAS, Scopus and Google Scholar

- Research which is freely available for redistribution

Submit your manuscript at www.biomedcentral.com/submit
C) Biomed Central 